\section{'Georgia Scarlet', Flowering Ornamental Cuphea llavea}

Casimir A. Jaworski

Agrrcultural Research Service, U.S. Department of Agriculture, Tifton, GA 31793

\author{
Sharad C. Phatak \\ University of Georgia, Tifton, GA 31793
}

Additional index words. ground cover, landscape plant

Cuphea, a genus in the Lythraceae, includes $\approx 260$ species and is a native mostly from Mexico through Brazil (Graham and Kleiman, 1985). Cuphea llavea (Lex.) is a native of Mexico (Graham, 1988). The primary interest in Cuphea spp. is to use its seeds as a potential source of medium-chain triglycerides; $C$. llavea seeds have an oil content of $22 \%$, with a capric acid content of $\approx 85 \%$ (Graham et al., 1981). However, an alternative use of some Cuphea spp. may be as landscape and ornamental plants (Jaworski and Phatak, 1990, 1991; Pottberg, 1984; Thompson et al., 1987).

Cuphea llavea selection 'Georgia Scarlet' has potential use as a perennial landscape and ornamental plant for the southeastern United States and as an annual bedding plant in regions to the north. This plant is adapted to full sun and has winter hardiness in U.S. Dept. of Agriculture Plant Hardiness Zone 8A (U.S. Dept. Agr., 1990). The plants produce a large mass of red flowers from midJune until mid-October. Natural propagation is by underground stolons and by rooting of prostrate shoots.

\section{Origin}

'Georgia Scarlet' was selected from eight of $100 C$. llavea plants and from two of 100 C. procumbens x C. llavea hybrid plants that survived Winter 1986-87 in Tifton, Ga. These 10 surviving plants were further evaluated in field trials using 10 replicates of single plants from naturally rooted shoots during 1987 through 1990. 'Georgia Scarlet' originated from one of the eight surviving $C$. llavea plants and was assigned Georgia number GA 02. These $C$. llavea plants were produced from seeds of Arizona accession number $\mathrm{A}$ 0074, now located at Ames, Iowa.

\section{Description}

Selection of 'Georgia Scarlet' was based on superior overwintering, superior ground cover $(66 \mathrm{~cm}$ in diameter at the end of the first season, $66 \mathrm{~cm}$ by the end of spring the second season, and $150 \mathrm{~cm}$ in diameter by

Received for publication 9 Oct. 1990. The cost of publishing this paper was defrayed in part by the payment of page charges. Under postal regulations, this paper therefore must be hereby marked advertisement solely to indicate this fact. the end of the second season), and short height $(26 \mathrm{~cm})$. 'Georgia Scarlet' shoot growth was prostrate instead-of upright as in other $C$. llavea.

'Georgia Scarlet' flowers $\approx 2$ weeks later than other C. llavea and most of its flowering is from mid-June through mid-October in Tifton; often averaging 11 to 16 open flowers $/ 100 \mathrm{~cm}^{2}$ (Fig. 1). Flowers contained two dorsal petals and no ventral petals. These dorsal petals are $0.7 \times 0.8 \mathrm{~cm}$ and are red (43A) (Royal Horticultural Society, 1966). Floral tube length is $2.3 \mathrm{~cm}$. The floral tube base is green (142 B), the floral tube top tip is violet $(83 \mathrm{~A})$, and the floral tube bottom tip is purple violet (81A). Maximum leaf size is $4.3 \times 1.2 \mathrm{~cm}$ and they are green (137A) and shiny. Leaves are simple, opposite, and usually oriented distinctly upward on the stem.

Plant parts above the ground are killed by freezing temperatures; however, the plant remains viable below the ground. The lowest temperature in Winter 1987-88, 1988-89, and 1989-90 was $-11 \mathrm{C}$. The adaptation of 'Georgia Scarlet' as permanent plantings in commercial and residential landscapes in colder regions has yet to be evaluated. Seeds are viable, but vegetative propagation will be essential to maintain characteristics true to the mother plant. Micropropagation using shoot explants would be a rapid and effective means of propagation of 'Georgia Scarlet' (Sultanbawa, 1990).

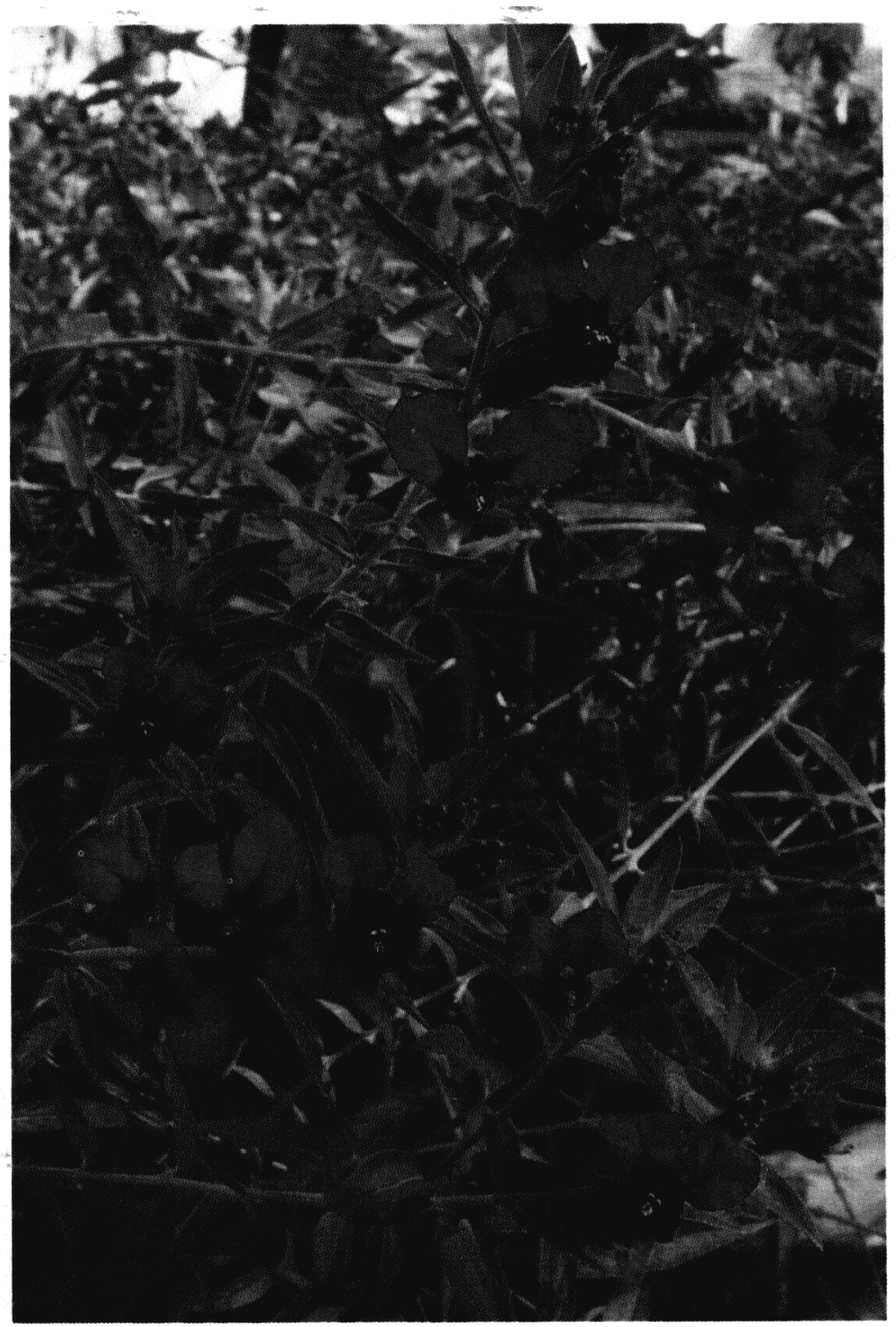

Fig. 1. 'Georgia Scarlet' Cuphea llavea. 


\section{Availability}

Information for propagation of 'Georgia Scarlet' can be obtained from S.C.P., Horticulture Dept., CFB, Univ. of Georgia, P.O. Box 748, Tifton, GA 31793.

\section{Literature Cited}

Graham, S.A. 1988. Revision of cuphea section heterodon (Lythraceae). Systematic Bot. Monogr. vol. 20. Amer. Soc. Plant Taxonomists.

Graham, S.A., F. Hirsinger, and G. Robbelen. 1981. Fatty acids of cuphea (Lythraceae) seed lipids and their systematic significance. Amer. J. Bot. 68:908-917.
Graham, S.A. and R. Kleiman. 1985. Fatty acid composition in cuphea seed oils from Brazil and Nicaragua. J. Amer. Oil Chem. Soc. 62:81-82. Jaworski, C.A. and S.C. Phatak. 1990. Cuphea glutinosa selections for ornamental ground cover in southeast United States, p. 467-469. In: J. Janick and J.E. Simon (eds.). Advances in new crops. Timber Press, Portland, Ore.

Jaworski, C.A. and S.C. Phatak. 1991. 'Lavender Lady', flowering ornamental Cuphea glutinosa. HortScience 26:221-222.

Pottberg, C.F. 1984. Cuphea plant table top bonsai [Cuphea hyssopifolia, dwarf size, internodal dwarfing, a spreading growth form and profuse substantially constant blooming]. U.S. Plan Patent 5214.
Royal Horticultural Society. 1966. Royal Horticultural Society colour chart. Royal Hort. Soc., London.

Sultanbawa, A.F. 1990. Protoplast and tissue culture of Cuphea lanceolata Ait. and tissue culture of Cuphea llavea Llav. \& Lex. and Cuphea glutinosa Cham \& Schldl. PhD Diss., Univ. of Georgia, Athens.

Thompson, A.E., D.T. Ray, and M.S. Roh. 1987. Evaluation of Cuphea procumbens x C. llavea hybrids as new floral and bedding plants. HortScience 22:1142-1143. (Abstr.)

U.S. Department of Agriculture. 1990. Plant hardiness zone map. U.S. Dept. Agr. Misc. Publ. 1475 . 